\title{
Reactive oxygen and nitrogen (ROS and RNS) species generation and cell death in tomato suspension cultures-Botrytis cinerea interaction
}

\author{
E. Pietrowska • S. Różalska • A. Kaźmierczak • \\ J. Nawrocka • U. Malolepsza
}

Received: 29 April 2014 / Accepted: 12 July 2014 / Published online: 27 July 2014

(C) The Author(s) 2014. This article is published with open access at Springerlink.com

\begin{abstract}
This article reports events connected to cell survival and Botrytis cinerea infection development in cell suspension cultures of two tomato cultivars which show different levels of susceptibility to the pathogen: cv. Corindo (more susceptible) and cv. Perkoz (less susceptible). In parallel changes in reactive oxygen (ROS) and nitrogen (RNS) species generation and in $S$-nitrosoglutathione reductase (GSNOR) activity were studied. In vivo staining methods with acridine orange (AO) and ethidium bromide (EB) as well as fluorescent microscopy were used to assess tomato and $B$. cinerea cells death. The biochemical studies of ROS and RNS concentrations in plant cell extract were complemented by in vivo ROS and nitric oxide (NO) imaging using nitro blue tetrazolium (NBT), diaminobenzidine (DAB) and diaminofluorescein diacetate (DAF-DA) staining methods, and confocal microscope technique. B. cinerea infection proceeded slower in Perkoz cell cultures. It was evidenced by measuring the pathogen conidia germination and germination tube development in which nuclei revealing cell death dominated. Two different types of tomato cell death were observed: cells with necrotic nuclei dominated in Corindo whereas in Perkoz cells with characteristic of vacuolar death type prevailed. In Perkoz cells, constitutive levels of NO and $S$-nitrosothiols (SNO) were significantly higher and hydrogen peroxide $\left(\mathrm{H}_{2} \mathrm{O}_{2}\right)$ and superoxide
\end{abstract}

Handling Editor: Friedrich W. Bentrup

E. Pietrowska $\cdot$ J. Nawrocka $\cdot$ U. Małolepsza $(\square)$

Department of Plant Physiology and Biochemistry, University of Lodz, Banacha 12/16, 90-237 Lodz, Poland

e-mail: ulmal@biol.uni.lodz.pl

\section{S. Różalska}

Department of Industrial Microbiology and Biotechnology, University of Lodz, Banacha 12/16, 90-237 Lodz, Poland

A. Kaźmierczak

Department of Cytophysiology, University of Lodz, Banacha 12/16, 90-237 Lodz, Poland anion $\left(\mathrm{O}_{2}{ }^{-}\right)$concentrations were slightly higher as compared with Corindo cells. Moreover, increases in these molecule concentrations as a result of $B$. cinerea inoculation were observed in both, Perkoz and Corindo cell cultures. The enzymatic GSNOR activity seems to be an important player in controlling the SNO level in tomato cells. Involvements of the studied compounds in molecular mechanisms of tomato resistance to $B$. cinerea are discussed in the paper.

Keywords $B$. cinerea $\cdot$ Cell death $\cdot$ Nitric oxide $\cdot$ Resistance $\cdot$ Tomato

\section{Introduction}

The necrotrophic pathogen Botrytis cinerea is a casual agent of gray mold in a broad host range (Elad et al. 2007; Finkers et al. 2007). It is one of the most devastating diseases of tomato grown in field and glasshouse conditions. The pathogen infects leaves, stems, flowers, and tomato fruits during cultivation as well as during transport and storage. Modern hybrid tomato cultivars are susceptible to $B$. cinerea. Although some cultivars show some level of resistance, commercially acceptable resistant tomato cultivars are not available so far.

$B$. cinerea is difficult to control because it has a variety of modes of attack, diverse hosts as inoculum source, and it can survive as mycelia and/or conidia for extended periods as sclerotia in crop debris. For these reasons, the use of any single control measure is unlikely to succeed and more detailed understanding of the biochemical bases of this hostpathogen interaction is essential (Williamson et al. 2007). Plant defense mechanisms against necrotrophs, such as B. cinerea, are complex, and despite extensive studies, their biochemical bases are still not fully understood and are a matter of controversial debate (Asai and Yoshioka 2009; 
Asselbergh et al. 2007; Floryszak-Wieczorek et al. 2007; Govrin and Levine 2000; Oirdi et al. 2011; Unger et al. 2005).

An oxidative burst, a common early response of host plant cells to pathogen attack and elicitor treatment, is one of the crucial components of plant defense responses (Delledonne et al. 2001; Zaninotto et al. 2006). Studies of various plantpathogen combinations have revealed a striking correlation between the profile of ROS formation and the outcome of the interaction (resistance or susceptibility) in plants. ROS, predominantly $\mathrm{O}_{2}{ }^{-}$and $\mathrm{H}_{2} \mathrm{O}_{2}$, overproduced during the oxidative burst may be directly involved in pathogen killing (Peng and Kuć 1992; Wang and Higgins 2005) and strengthening of a plant cell wall as well as in triggering hypersensitive cell death (HR) and in production of systemic resistance signaling (Delledonne et al. 2001; Zaninotto et al. 2006). Death of attacked cells during HR, preceded by oxidative burst, has been considered an important element of successful defense strategy of plants against biotrophic pathogens feeding on living host tissues. Enhanced ROS generation was also found to accompany an infection caused by necrotrophs, but in that case, their role in the interaction is still controversial; death of host cells during HR is considered advantageous for the pathogen. Necrotrophs kill their host cells by secreting toxic compounds or lytic enzymes, and in addition, they produce different pathogenic factors that can subdue host defense. The ability of the fungus to kill cells was proposed as an important determinant in host susceptibility to different Botrytis species; plant resistance to the pathogen is supposed to depend on the balance between cell death and survival (van Barleen et al. 2007; Asselbergh et al. 2007). ROS production does not always result in increased susceptibility, because failure or success of infection by $B$. cinerea appears to depend strongly on the timing and the intensity of oxidative burst (Asai and Yoshioka 2009; Asselbergh et al. 2007; Kunz et al. 2006; Shlezinger et al. 2011).

Considerable evidence indicates that ROS generation is accompanied by nitric oxide (NO) synthesis (Asai and Yoshioka 2009; Chaki et al. 2009; Zaninotto et al. 2006). NO and ROS interplay is of special interest in plant disease resistance initiation and execution. Nitric oxide together with ROS have been identified as essential molecules that mediate cell death in HR and defense gene activation (Lin et al. 2012; Zaninotto et al. 2006). It is suggested that $S$ - nitrosoglutathione acts as a long-distance signal in systemic acquired resistance (SAR) that might act both as NO reservoir and NO donor (Lindermayr et al. 2005; Restérucci et al. 2007); NO is indispensable to salicylic acid (SA) functioning as SAR inducer (Malik et al. 2011; RomeroPuertas and Delledonne 2003). S-nitrosylation, addition of NO moiety to Cys thiol to form $S$-nitrosothiol (SNO), has now emerged as a key redox-based posttranslational modification in plants and a major route for the transduction of $\mathrm{NO}$ bioactivity integral to plant immune function (Feechan et al. 2005; Lin et al. 2012; Malik et al. 2011). Growing evidence suggests that NO and SNO are important mediators in the process of plant cell death induction and orchestration (de Pinto et al. 2012; Lin et al. 2012; Malik et al. 2011). Cellular SNO level is regulated by $S$ nitrosoglutathione reductase (GSNOR). The function of this enzyme is conserved between bacteria, animals, and plants (Liu 2001; Lin et al. 2012). GSNOR seems to be an important player in plant de-nitrosylation, especially during development of disease response; however, its precise role in this process is far from being clear (Feechan et al. 2005; Malik et al. 2011; Wang et al. 2009).

Accumulating evidence suggests that both NO and ROS play key roles in programmed cell death (PCD) which is an integral part of plant development and defense. Relatively, little is known about PCD in plants, and detailed mechanisms underlying this still need elucidation. Various types of plant PCD have been proposed (Love et al. 2008; van Doorn et al. 2011; Byczkowska et al. 2013). Two major types of plant cell death have been described: vacuolar cell death and necrosis. Vacuolar cell death is connected with formation of lytic vacuoles, tonoplast rupture, and releasing of hydrolases, gradual decreasing cytoplasm as well as nuclei segmentation and chromatin condensation. This type of PCD mainly occurs during normal plant development and after mild abiotic stress. Necrosis is characterized by early rupture of plasma membrane, shrinking of protoplast, and absence of growing lytic vacuoles. The third type of plant cell death is connected with HR response to pathogens which can express features of both necrosis and vacuolar cell death (van Doorn et al. 2011). HR exhibits different patterns of cellular changes depending on host-pathogen interactions. This type of cell death has been observed during interactions with biotrophic as well as necrotrophic pathogens. HR usually occurs at the site of successful recognition of biotrophic pathogens feeding on living host tissues. Cell death at the site of pathogen attack restricts pathogen invasion and disease development. On the contrary, the ability of the necrotrophic pathogens to kill cells was proposed as a determinant in host susceptibility. However, the data regarding HR cell death contribution to the defense responses associated with necrotrophic pathogens are contradictory.

In the present work, using cell cultures of two tomato cultivars differing in resistance to $B$. cinerea, we undertook a biochemical and cellular study of changes in ROS, NO, SNO, MDA concentrations, and GSNOR activity as well as tomato cell viability and the pathogen infection development to explain the biochemical bases of tomato resistance to the pathogen.

\section{Material and methods}

Plant material

Cell suspension cultures of two tomato (Solanum lycopersicum L.) cultivars: Corindo-more susceptible to 
B. cinerea and Perkoz-less susceptible were grown in Chandler medium supplemented with BAP $0.2 \mathrm{mg} \mathrm{dm}^{-3}$ and 2,4 D $1.0 \mathrm{mg} \mathrm{dm}^{-3}$ (Chandler et al. 1972). Established cell cultures were subcultured by pipetting $25 \mathrm{~cm}^{3}$ of 7-day-old cultures into $75 \mathrm{~cm}^{3}$ of fresh growth medium in $300 \mathrm{~cm}^{3}$ Erlenmeyer flasks. The subcultured cell cultures were grown in the dark at $25{ }^{\circ} \mathrm{C}$, on a rotating platform at $120 \mathrm{rpm}$. Three-day-old cultures with cell density $10^{6} \mathrm{~cm}^{-3}$ were taken to experiments; some of them were inoculated with $2 \mathrm{~cm}^{3} B$. cinerea conidia suspension $\left(10^{5} \mathrm{~cm}^{-3}\right)$. Control, noninoculated, and pathogen inoculated cell cultures were harvested and examined 6, 12, 24, and $48 \mathrm{~h}$ postinoculation (hpi). The cells were separated from the growth medium using vacuum-assisted filtration through two layers of Miracloth (Calbiochem, San Diego, CA, USA).

\section{B. cinerea culture}

B. cinerea isolate 1631 was provided by Bank of Plant Pathogens (Poznań, Poland) and was maintained in stock culture on potato dextrose agar in the dark at $24^{\circ} \mathrm{C}$. The conidial suspension was obtained by washing potato dextrose agar slant cultures with tap water. $1 \times 10^{5} \mathrm{~cm}^{-3}$ conidial suspension was used to inoculate tomato cell cultures.

Assay of $B$. cinerea infection development in tomato cell cultures

B. cinerea infection development in tomato cell cultures was assayed as a percentage of conidia germination. The percentage of germinated $B$. cinerea conidia was determined microscopically 6, 12, 24, and 48 hpi. Conidia were considered germinated when the length of germ tubes exceeded the diameter of the conidium.

Assay of viability of cell cultures

The Evans blue method was used to test cell viability/death according to Kanai and Edwards (1973) with modification. Briefly, $1 \mathrm{~cm}^{3}$ of Evans blue solution $(0.25 \%$ Evans blue in $3 \mathrm{mM} \mathrm{CaCl}_{2}$ and $0.6 \mathrm{M}$ mannitol) was added to $0.1 \mathrm{~g}$ of cells for $10 \mathrm{~min}$. The cells were washed in $2 \mathrm{~cm}^{3}$ of water for 30 min. Drops of cell suspension were put on FüschRosenthal camera and analyzed using light microscope. Dead (dark blue) and viable (non-stained) cells were counted in twenty samples for each treatment, with every experiment repeated at least three times.

Assay of cell death by fluorescent microscopy

Detection and verification of cell death in the suspension of cells were carried out according to the following procedure:
(1) Culture medium $\left(0.5 \mathrm{~cm}^{3}\right)$ with $0.5 \mathrm{~cm}^{3}$ of appropriate cell suspension was supplemented with $0.5 \mathrm{~cm}^{3}$ of $0.02 \mathrm{M}$ phosphate buffer $\mathrm{pH} 7.4$ (PHB).

(2) The cells were stained with the staining mixture containing $50 \mu \mathrm{g} \mathrm{cm}^{-3} \mathrm{AO}$ (acridine orange) and $50 \mu \mathrm{g} \mathrm{cm}^{-3} \mathrm{~EB}$ (ethidium bromide) at PHB.

(3) Drops of cell suspension were immediately put on glass slides and analyzed for 5 min using fluorescent microscopy with a blue light (B2A) excitation filter of the Optiphot-2 epi-fluorescence microscope (Nikon) equipped with a camera and Act-1 software (Precoptic, Poland) for fluorescent microscopy and preparation of microphotographs according to Byczkowska et al. 2013.

$\mathrm{AO} / \mathrm{EB}$ staining consists in staining with $\mathrm{AO}$ which permeates whole cells and makes the nuclei green and with EB which is only taken up by cells when the cellular and nuclear membrane integrity is lost and stains the nuclei red. EB also dominates over AO (Ribble et al. 2005; Kobori et al. 2007). It has been reported (Kobori et al. 2007; Byczkowska et al. 2013) that under fluorescence microscope, living cells have unchanged green nuclei while dying cells have green-yellow, yellow, yellow-orange, and bright orange nuclei with slightly condensed or fragmented chromatin at the early stage of death while at the late one with condensed and fragmented chromatin. Necrotic cells have structurally normal orange nuclei (Ribble et al. 2005; Byczkowska et al. 2013). These cells were described as dead (Byczkowska et al. 2013). When the color is changed from green to red, values of fluorescence intensity of both fluorochromes increase. Thus, according to the values of curve of the resultant fluorescence intensity (Byczkowska et al. 2013) it is possible to assign cells as alive, dying or dead and present their number in appropriate index (Byczkowska et al. 2013).

Assay of nitro blue tetrazolium reducing activity

Measurement of nitro blue tetrazolium (NBT) (Sigma-Aldrich Chemie GmbH, Steinheim, Germany) reduction, a method used for the determination of $\mathrm{O}_{2}{ }^{-}$, was described by Doke (1983). Twenty-five milligrams of cells were resuspended in $3 \mathrm{~cm}^{3} 0.01 \mathrm{M}$ potassium phosphate buffer $\mathrm{pH} 7.8$ containing $0.05 \% \mathrm{NBT}_{\text {and }} 10 \mathrm{mM} \mathrm{NaN}_{3}$ (Sigma-Aldrich) for $1 \mathrm{~h}$. After removing the cells by filtration through paper filter, the mixture was heated at $85{ }^{\circ} \mathrm{C}$ for $15 \mathrm{~min}$ and cooled. The NBT reducing activity of the cells was expressed as increased absorbance at $580 \mathrm{~nm} \mathrm{~h}^{-1} \mathrm{~g}^{-1}$ of fresh weight. The effect of SOD on the reduction of NBT by the cells was determined by adding SOD (manganese-containing enzyme) (SigmaAldrich) $\left(100 \mu \mathrm{g} \mathrm{ml}^{-1}\right)$ to the reaction solution from which $\mathrm{NaN}_{3}$ was omitted. 
Assay of hydrogen peroxide concentration

Hydrogen peroxide was measured by the method described by Capaldi and Taylor (1983) with slight modifications. Two hundred fifty milligrams of cells were ground in $2.5 \mathrm{~cm}^{3}$ $5 \%$ TCA with $50 \mathrm{mg}$ active charcoal at $0{ }^{\circ} \mathrm{C}$ and centrifuged for $10 \mathrm{~min}$ at $15,000 \mathrm{~g}$. Supernatant was collected, neutralized with $4 \mathrm{~N} \mathrm{KOH}$ to $\mathrm{pH} 3.6$ and used for $\mathrm{H}_{2} \mathrm{O}_{2}$ assay. The reaction mixture contained $200 \mu \mathrm{l}$ of cell extract, $100 \mu \mathrm{l}$ of 3.4 mM 3-methylbenzothiazoline hydrazone (MBTH, SigmaAldrich). The reaction was initiated by adding $500 \mu \mathrm{l}$ of horseradish peroxidase (Fluka Chemie $\mathrm{GmbH}$ ) solution (90 $\mathrm{U}$ per $100 \mathrm{~cm}^{3}$ ) in $0.2 \mathrm{M}$ sodium acetate buffer $\mathrm{pH}$ 3.6. Two minutes later, 1,400 $\mu$ l of $1 \mathrm{~N} \mathrm{HCl}$ was added. Absorbance was determined at $630 \mathrm{~nm} . \mathrm{H}_{2} \mathrm{O}_{2}$ concentration was calculated based on a standard curve of the $\mathrm{H}_{2} \mathrm{O}_{2}$ and expressed in $\mu \mathrm{mol} \mathrm{g}{ }^{-1}$ fresh weight.

Assay of nitric oxide concentration

Nitric oxide content was determined using the method described by Ding et al. (1988) with slight modifications. Six hundred milligrams of cells were ground in $3 \mathrm{~cm}^{3}$ of $50 \mathrm{mM}$ cool acetic acid buffer pH 3.6 containing $4 \%$ zinc diacetate. The homogenate was centrifuged at $10,000 \mathrm{~g}$ for $15 \mathrm{~min}$ at $4{ }^{\circ} \mathrm{C}$. The supernatant was collected. The pellet was washed by $1 \mathrm{~cm}^{3}$ extraction buffer and centrifuged as before. The two supernatants were combined and $0.1 \mathrm{~g}$ of charcoal was added. After vortex and filtration, the filtrate was leached and collected. The mixture of $1 \mathrm{~cm}^{3}$ of filtrate and $1 \mathrm{~cm}^{3}$ of the Griess reagent (Sigma-Aldrich) was incubated at room temperature for $30 \mathrm{~min}$. Absorbance was determined at $540 \mathrm{~nm}$. NO content was calculated by comparison to a standard curve of $\mathrm{NaNO}_{2}$.

\section{Assay of in situ NO accumulation}

Five microliter of $10 \mathrm{mM}$ stock solution of 4,5diaminofluorescein diacetate (DAF-2DA) in DMSO (SigmaAldrich) - the probe used for visualization of NO, was added to $2.5 \mathrm{~cm}^{3}$ of cell suspension culture. After 30-min incubation at $25{ }^{\circ} \mathrm{C}$ in the dark, the cells were filtered and washed with $10 \mathrm{mM}$ Tris- $\mathrm{HCl}$ buffer $\mathrm{pH} 7.0$, mounted in the buffer on microscope slides, and then examined immediately under confocal laser scanning microscope Pascal 5 (Zeiss). The cells were excited with the 488 line of an argon laser. The emission was recorded using a 530-nm bandpass filter. For Nomarski DIC the same laser line as described above was used. Constant exposure time was used for all experiments. The production of green fluorescence under these conditions was attributed to the presence of NO (Foissner et al. 2000). The slides were scanned into a computer. Microscope, laser, and photo multiplier settings were held constant during the course of all experiments in order to obtain comparable results from observation of at least triplicate samples from each experiment, with every experiment repeated at least three times.

\section{Assay of SNO concentration}

Total SNO levels were determined according to Restérucci et al. 2007. Proteins were extracted in $100 \mathrm{mM}$ Tris- $\mathrm{HCl}$, $\mathrm{pH}$ 6.8. The extracts were incubated for $5 \mathrm{~min}$ with an equivalent volume of solution A (1\% sulfanilamide dissolved in $0.5 \mathrm{M} \mathrm{HCl}$ ) in the presence or absence of solution B (solution A plus $0.2 \% \mathrm{HgCl}_{2}$ ), allowing the development of the diazonium salt. The formation of the azo dye product was obtained by reacting the two samples for an additional 5 min with an equal volume of solution $\mathrm{C}[0.02 \%$ of $\mathrm{N}$-(1-naphthyl) ethylenediamine dihydrochloride dissolved in $0.5 \mathrm{M} \mathrm{HCl}$, and the absorbance was subsequently read at $550 \mathrm{~nm}$ with spectrophotometer (Hitachi, F-2500). SNO was quantified as the difference of absorbance between solution B and A (B-A), comparing the values with a standard curve made from solution of GSNO (Sigma-Aldrich). The results were normalized per milligram of protein measured by the Bradford (1976) method.

Assay of in situ accumulation of $\mathrm{O}_{2} \cdot{ }^{-}$and $\mathrm{H}_{2} \mathrm{O}_{2}$

In situ generation of $\mathrm{O}_{2}{ }^{--}$, was visualized using $\mathrm{NBT}$ forming dark blue insoluble precipitate in the presence of $\mathrm{O}_{2}{ }^{--}$. Such reaction was not observed in the presence of SOD (data not shown). A modified method described by Trujillo et al. (2004) was used. The control and $B$. cinerea inoculated cells were collected at $12 \mathrm{hpi}$ and incubated with $0.1 \%$ solution of NBT in $10 \mathrm{mM}$ phosphate buffer $\mathrm{pH} 7.8$ containing $10 \mathrm{nM} \mathrm{Na}$ azide for $3 \mathrm{~h}$ in the light and at room temperature.

In situ generation of $\mathrm{H}_{2} \mathrm{O}_{2}$ was detected by formation of brown precipitate after incubation of the cells with a solution of $1 \mathrm{mg} \mathrm{cm} \mathrm{cm}^{-3} 3,3^{\prime}$-diaminobenzidine-tetrahydrochloride (DAB) (Sigma-Aldrich) $\mathrm{pH} 3.8$ for $8 \mathrm{~h}$ in the light and at room temperature according to the modified method of Orozco-Cárdenas and Ryan (1999). The cells were preserved in cool ethanol and photographed with Axiovert $200 \mathrm{M}$ inverted microscope equipped with HRC digital camera (Zeiss).

Assay of lipid peroxidation (MDA content)

Lipid peroxidation was determined by measuring the concentration of thiobarbituric acid-reactive substances (TBARS) MDA content according to Yagi (1976) with modifications. The biomass of $0.5 \mathrm{~g}$ of cells was mechanically homogenized $(1: 10 w / v)$ with a $50 \mathrm{mM}$ sodium phosphate buffer $\mathrm{pH} 7.0$ containing $1 \mathrm{~N} \mathrm{NaCl}, 1 \%$ PVP (Sigma-Aldrich) MW 40,000, and $1 \mathrm{mM}$ ascorbate (Sigma-Aldrich) at $4{ }^{\circ} \mathrm{C}$. After 
centrifugation at $15,000 \mathrm{~g}$ for $15 \mathrm{~min}$, the supernatant was collected. The supernatant was mixed with TBA solution $(1: 1 \mathrm{v} / \mathrm{v})$ and heated at $95{ }^{\circ} \mathrm{C}$ for $1 \mathrm{~h}$. After cooling, the samples were supplied with $n$-butanol and intensively shaken. After centrifugation $(10,000 \mathrm{~g}, 10 \mathrm{~min})$, the obtained organic layer was separated and its fluorescence was measured at $531 \mathrm{~nm}$ (excitation) and $553 \mathrm{~nm}$ (emission) with fluorescence spectrometer. The concentration of MDA was estimated by referring to a standard 1,1,3,3-tetraetoxypropane and expressed as $\mathrm{nM}$ of MDA calculated per $1 \mathrm{~g}$ fw.

\section{Preparation of enzyme extracts}

At $4{ }^{\circ} \mathrm{C}, 0.25 \mathrm{~g}$ of cells was homogenized in $2.50 \mathrm{~cm}^{3}$ of $50 \mathrm{mM}$ Tris- $\mathrm{HCl}$ buffer $\mathrm{pH} 8.0$ containing $0.5 \mathrm{M} \mathrm{NaCl}$. After centrifugation at $15,000 \mathrm{~g}$ for $15 \mathrm{~min}$, the supernatant was collected.

Assay of $S$-nitrosoglutathione reductase (GSNOR) activity

GSNOR activity was determined by the modified method of Sakamoto et al. (2002). Enzyme activity was measured spectrophotometrically at $25{ }^{\circ} \mathrm{C}$ by monitoring the decomposition of NADH at $340 \mathrm{~nm}$. The reaction mixture contained $20 \mathrm{mM}$ Tris-HCl buffer $\mathrm{pH}$ 8.0, $0.2 \mathrm{mM} \mathrm{NADH}, 0.5 \mathrm{mM}$ EDTA, and GSNO with final concentration $400 \mu \mathrm{M}$. GSNOR enzyme activity was calculated taking into account the millimolar extinction coefficient of NADH $\varepsilon=6.22 \mathrm{mM} \mathrm{cm}^{-1}$ at $340 \mathrm{~nm}$ and presented in NADH $\mathrm{min}^{-1} \mathrm{mg}^{-1}$ of protein.

Assay of protein content

Protein was determined by the method of Bradford (1976) with standard curves prepared using bovine serum albumin (Sigma-Aldrich).

\section{Statistical analysis}

The significance of differences between mean values obtained from four independent experiments with three replicates each was determined by Student's-test. Sample variability is given as standard deviation (S.D.). Differences at $p<0.05$ were considered significant.

\section{Results}

B. cinerea infection development and plant cell viability in tomato cell cultures

Evans blue staining and fluorescence analyses under the fluorescence microscopy after successive addition of fluorochromes $\mathrm{AO} / \mathrm{EB}$ revealed that $B$. cinerea infection development proceeded slower in tomato cell cultures of $\mathrm{cv}$. Perkoz than in cv. Corindo. Conidia of the pathogen started to germinate in both cell cultures at $6 \mathrm{hpi}$, but at that time, $38 \%$ of conidia germinated in Corindo and $22 \%$ in Perkoz cell cultures, respectively (Fig. 1). About $45 \%$ of conidia germinated and formed shorter, swollen germination tubes with yellow-orange nuclei in Perkoz cell cultures (Figs. 1, 2, and 3a) which suggested that cells of the fungus died in vacuolar type of death. At that time, $70 \%$ of conidia germinated and formed long and slender germination tubes with green, alive nuclei in Corindo cell cultures 12 hpi (Figs. 1, 2, and $3 \mathrm{~b}$ ). Infection proceeded and about $80 \%$ of conidia germinated in both studied cell cultures at 24 hpi. Parallel to infection development, the viability of tomato cells was reduced from about $88 \%$ in healthy cell cultures to 74 and $64 \%$, respectively, in Perkoz and Corindo ones at 12 hpi (Fig. 4). Round, uniformly green stained, large central nuclei were observed among alive cells of both cultures (Fig. 5a, c). Green-yellow and yellow nuclei with slightly condensed chromatin dominated among dying cells, indicating that these cells underwent early stages of cell death in the pathogen inoculated Perkoz cell cultures at that time (Fig. 5b). Cell death of those cells was accompanied by the characteristics that are proposed to be associated with vacuolar plant cell death. Partial disappearance of nuclei and nuclei with dark orange chromatin were visible in Corindo cells, suggesting necrotic type of cell death (Fig. $5 \mathrm{~d}$ ). About $50 \%$ of the cells were dead in both cell cultures at $24 \mathrm{hpi}$; in both cultures, no viable cells were observed $48 \mathrm{~h}$ after challenge (Fig. 4).

Content and cellular localization of ROS and NO generation during tomato cell cultures $-B$. cinerea interaction

NBT and DAB staining used for and microscopy detections of $\mathrm{O}_{2}{ }^{--}$and $\mathrm{H}_{2} \mathrm{O}_{2}$, respectively, as well as $\mathrm{NO}$ detection by CLSM system were carried out following biochemical,

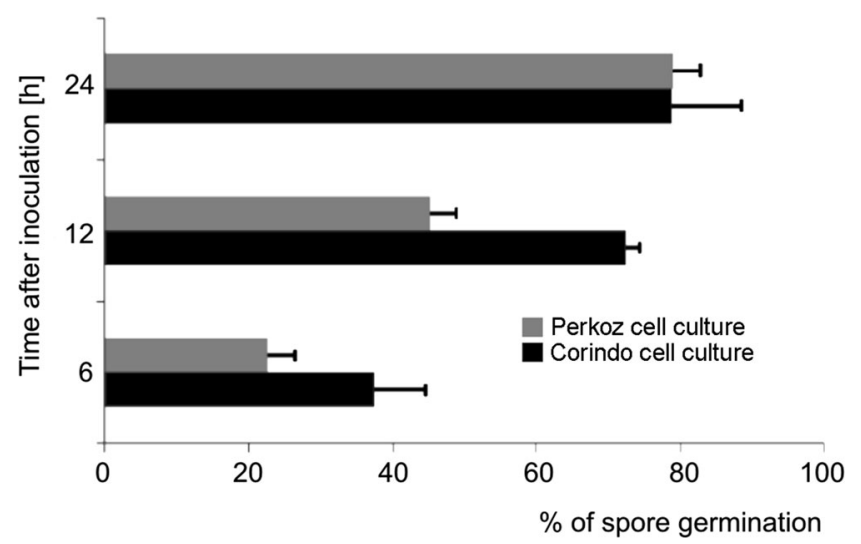

Fig. 1 B. cinerea conidia germination in tomato cell cultures. Values represent the means and S.D. from four independent experiments with three replicates each, $n=12$ 

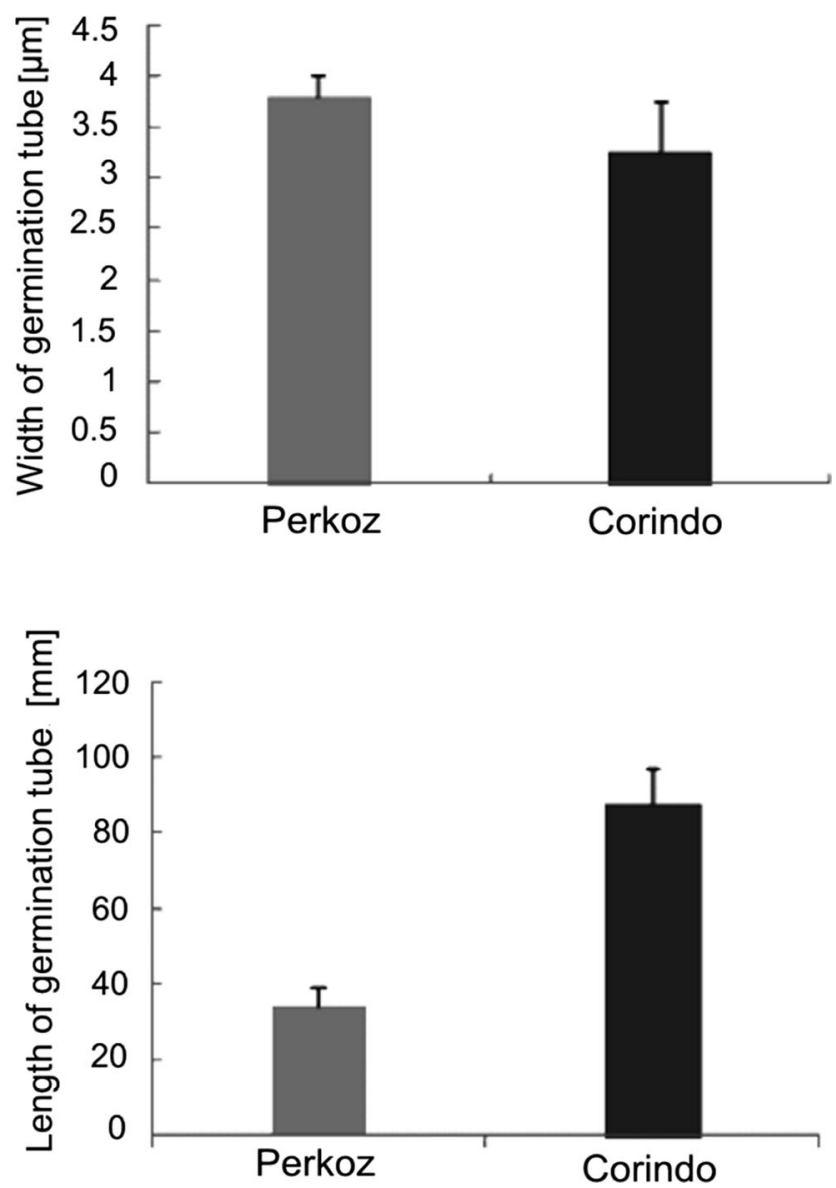

Fig. 2 B. cinerea germination tube development in tomato cell cultures at 12 hpi. Data and statistic as in Fig. 1

quantitative measurements of ROS, and NO. The data indicated that constitutive level of $\mathrm{O}_{2}^{--}$was about two times higher, and $\mathrm{H}_{2} \mathrm{O}_{2}$ level was slightly higher in Perkoz than in Corindo (Figs. 6a,b, 7a-d, 8a,b and 9a-d). Constitutive, preinoculation NO concentration in Perkoz cell cultures was
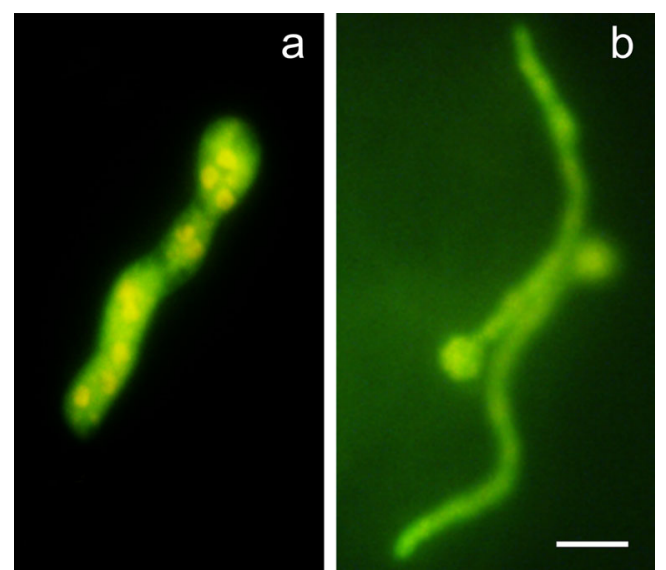

Fig. 3 Yellow-orange nuclei in cells dying via vacuolar type of death of B. cinerea germination tubes in Perkoz cell culture (a) and green nuclei in living cells of $B$. cinerea germination tubes in Corindo cell culture (b) at $12 \mathrm{hpi}$, detected by staining by AO/EB. Bar: $20 \mu \mathrm{m}$ is applied to (a) and (b)

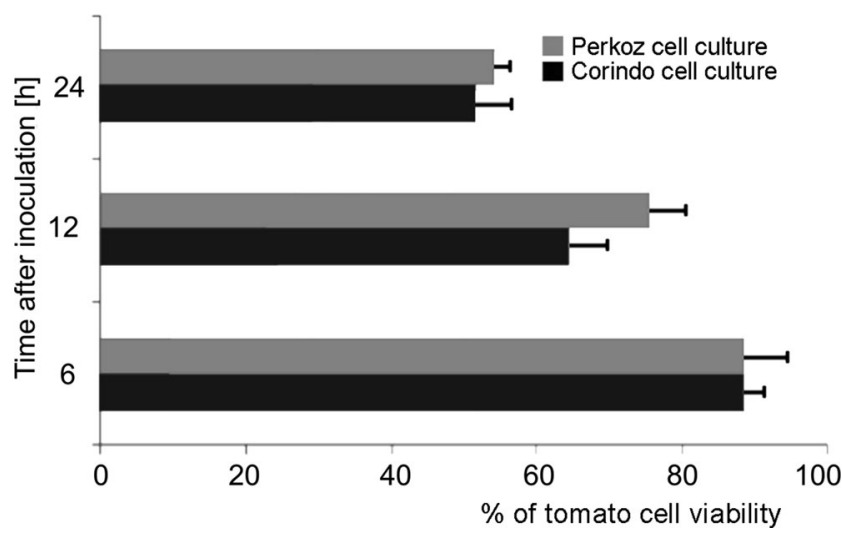

Fig. 4 Cell viability in tomato cell cultures inoculated with $B$. cinerea. Data and statistic as in Fig. 1

about $15 \mathrm{nmol} \mathrm{g}^{-1} \mathrm{fw}$, about three-fold greater than in Corindo ones (about $5 \mathrm{nmol} \mathrm{gfw}^{-1}$ ) (Figs. 10a, b). Both tomato cell cultures reacted to inoculation with $B$. cinerea with enhanced synthesis of $\mathrm{O}_{2}^{--}, \mathrm{H}_{2} \mathrm{O}_{2}$ and NO. In Perkoz, $\mathrm{O}_{2}{ }^{-}$generation measured as NBT reducing activity was about two times higher than in non-inoculated cultures at $6 \mathrm{hpi}$; this difference persisted throughout the experiment (Figs. 6a and 7a, b). Similarly, threefold increase in $\mathrm{O}_{2}{ }^{-}$concentration was observed in Corindo cell culture as a result of the pathogen inoculation (Fig. 6b). $\mathrm{H}_{2} \mathrm{O}_{2}$ concentration in the inoculated Perkoz cell cultures reached the maximal level $4 \mu \mathrm{mol} \mathrm{g}^{-1} \mathrm{fw}$, about two times higher than in the control, as early as $6 \mathrm{hpi}$, and it persisted for up to 24 hpi (Fig. 8a, and 9a, b). The $\mathrm{H}_{2} \mathrm{O}_{2}$ concentration in the inoculated Corindo cell cultures increased to $3 \mu \mathrm{mol} \mathrm{g}{ }^{-1} \mathrm{fw}$ at 6 and to $3.5 \mu \mathrm{mol} \mathrm{g}-1$ fw at 12 and $24 \mathrm{hpi}$, respectively (Figs. 8b, and 9c, d).

Nitric oxide concentration in Perkoz cell cultures reached $33 \mathrm{nmol} \mathrm{gfw}^{-1}$, the value two times higher than in the control at 6 hpi (Fig. 10a). After this significant increase, the decreasing trend in the level of $\mathrm{NO}$ to $25 \mathrm{nmol} \mathrm{g}^{-1} \mathrm{fw}$ at 12 hpi was
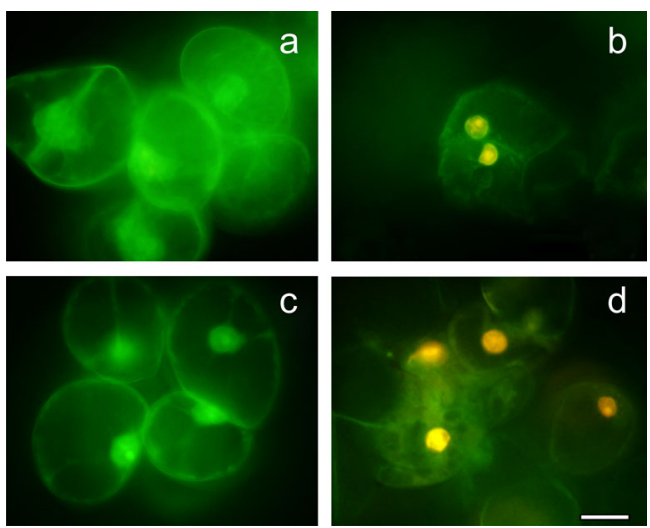

Fig. 5 Micrographs of living and dying tomato cells detected by AO/EB staining. Green nuclei of living control cells in Perkoz (a) and Corino (c) cultures, yellow nuclei of cells dying via vacuolar type of death (b) in B. cinerea-inoculated (12 hpi) Perkoz cell culture, orange-bright-red nuclei of necrotic cells (d) in $B$. cinerea-inoculated (12 hpi) Corindo cell culture. Bar: $20 \mu \mathrm{m}$ is applied to (a-d) 
Fig. 6 Superoxide anion concentration in Perkoz (a) and Corindo (b) cell cultures. Data and statistic as in Fig. 1; $* * P<0.01$ indicate values that differ significantly from the control

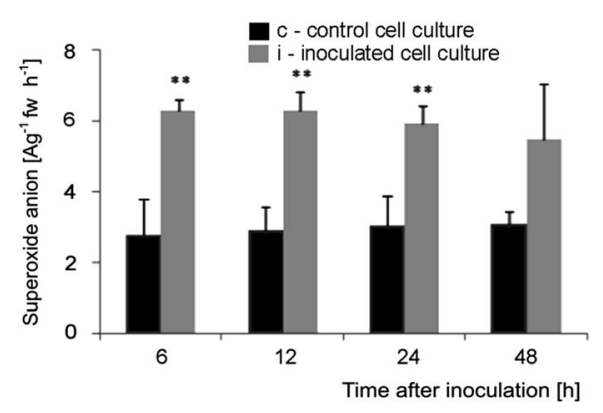

b

a

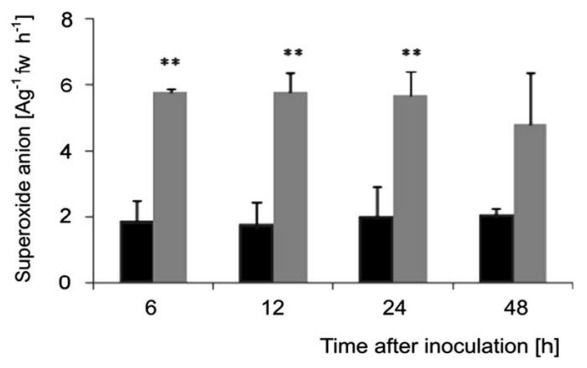

observed in the inoculated cultures, than the next increase in NO generation at $48 \mathrm{hpi}$ to $23 \mathrm{nmol} \mathrm{g}^{-1} \mathrm{fw}$ was noticed while NO level $15 \mathrm{nmol} \mathrm{g}^{-1} \mathrm{fw}$ was observed in the non-inoculated cultures. Similar trend of changes in NO concentrations was observed in Corindo cell cultures inoculated with the pathogen (Fig. 10b). Nitric oxide concentration in those cultures first increased $12 \mathrm{hpi}$ to $10 \mathrm{nmol} \mathrm{g}^{-1} \mathrm{fw}$, and then the increases were observed at $24 \mathrm{hpi}$ to $16 \mathrm{nmol} \mathrm{g}^{-1} \mathrm{fw}$ and $48 \mathrm{hpi}$ when NO concentration in the inoculated cultures reached $12 \mathrm{nmol} \mathrm{g}^{-1} \mathrm{fw}$ (Fig. 10b). Similar differences in NO content in the tomato cells were observed when the molecule was evaluated by CLSM (Fig. 11a-j)

SNO content during tomato cell cultures - B. cinerea interaction

Constitutive SNO level in Perkoz cell cultures reached $600 \mathrm{pg} \mathrm{mg}^{-1}$ protein and was about two times higher than in Corindo (Figs. 12a, b). SNO concentration in Perkoz cultures markedly increased to about $700 \mathrm{pg} \mathrm{mg}^{-1}$ protein at $6 \mathrm{hpi}$; the next, similar increase in SNO concentration was observed in those cultures $24 \mathrm{hpi}$. SNO concentration in Corindo cell cultures increased only at 24 hpi when it reached the maximal level $600 \mathrm{pg} \mathrm{mg}^{-1}$ protein.

Lipid peroxidation during tomato cell cultures $-B$. cinerea interaction

The extent of cell damage caused by reactive oxygen species and nitric oxide related to cell culture response to pathogen infection was estimated by the measurement of malonodialdehyde (MDA) content, the product of lipids peroxidation. In Corindo cell cultures inoculated with the pathogen, MDA content started to increase already 6 hpi, was significantly higher as compared to the control at 12 and 24 hpi and reached the highest, strongly significant level at
Fig. 7 Superoxide anion detected by NBT staining in Perkoz control (a) and B. cinerea inoculated (b) cell cultures and in Corindo control (c) and B. cinerea inoculated (d) cell cultures at 12 hpi. Bar: $20 \mu \mathrm{m}$ is applied to (a-d)
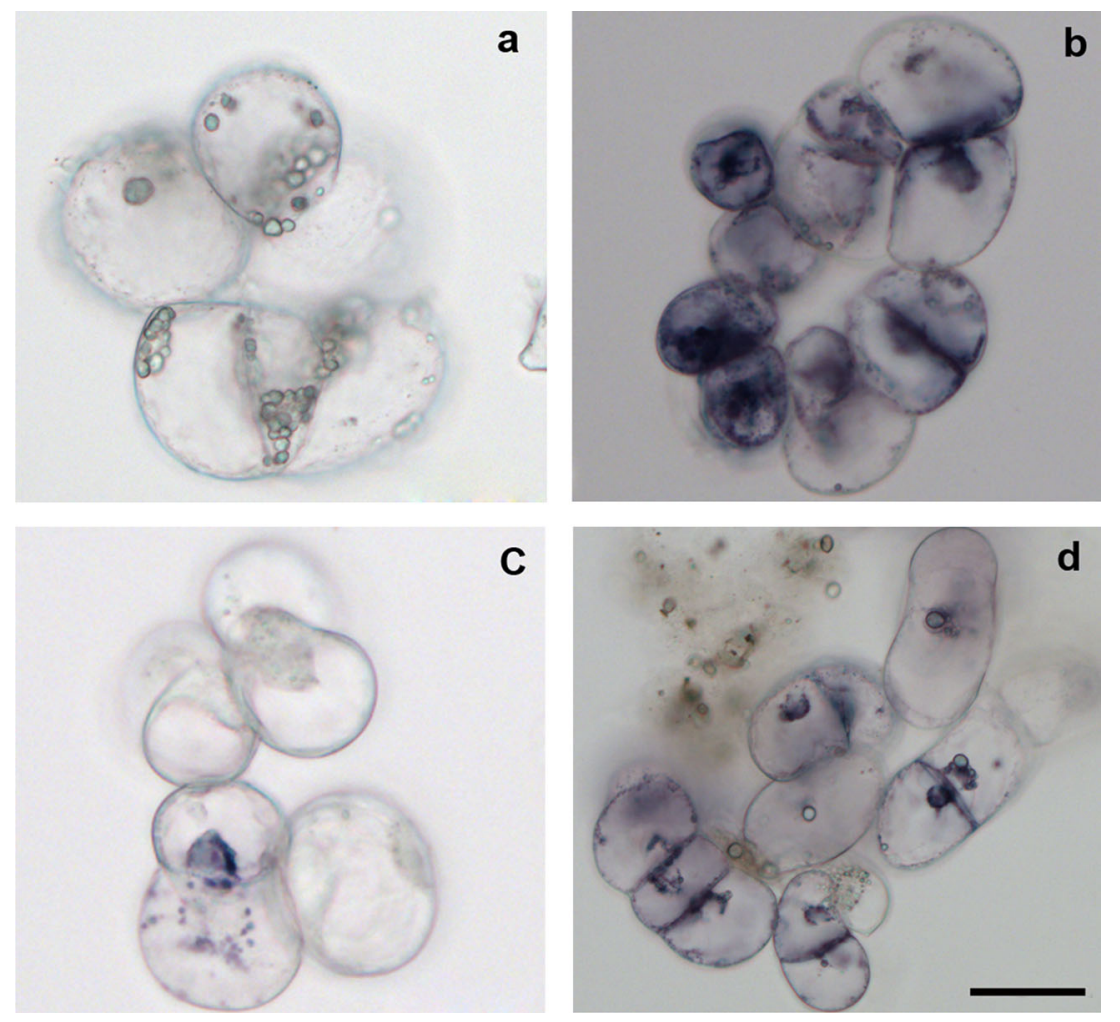


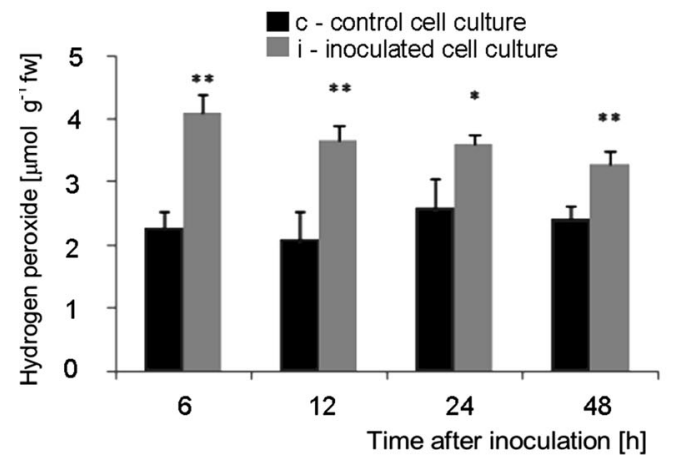

a

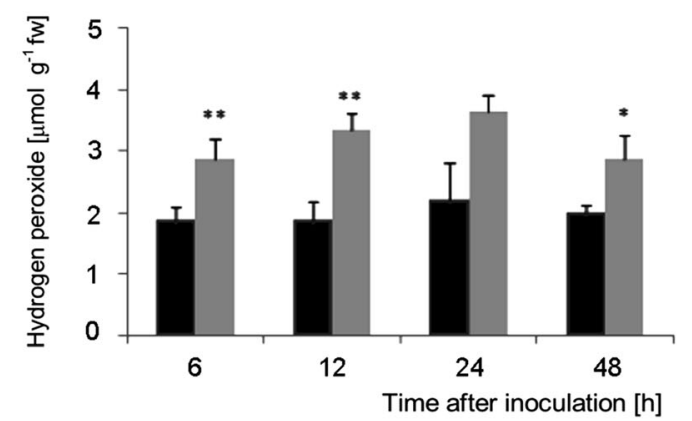

Fig. 8 Hydrogen peroxide concentration in Perkoz (a) and Corindo (b) cell cultures. Data and statistic as in Fig. $1 ; * P<0.05$ and $* * P<0.01$ indicate values that differ significantly from the control

48 hpi (Fig. 13b). MDA concentration in Perkoz cell cultures increased less significantly only at the last stage of interaction (48 hpi) when there were no viable tomato cells in the culture (Fig. 13a).

GSNOR activity during tomato cell cultures - B. cinerea interaction

The constitutive activity level of $S$-nitrosoglutathione reductase (GSNOR) was twice higher in Corindo cell cultures as compared with Perkoz ones (Figs. 14a, b). In Perkoz cell cultures, the enzyme activities started to increase already $6 \mathrm{hpi}$ and reached the maximal, above two times higher level of activity as compared to the control at $12 \mathrm{hpi}$. The next, similar increase in the enzyme activity was observed at 48 hpi. In Corindo cell cultures inoculated with the pathogen, the increases in GSNOR activity were observed at 12 and 48 hpi, the latter being greater, twice higher than the control.

\section{Discussion}

The present study investigated the $B$. cinerea infection development in tomato cell cultures of cv. Perkoz and cv. Corindo, less and more susceptible to the pathogen, respectively. Simultaneously, the effects of the pathogen on dying tomato cells and production of ROS, NO, SNO, MDA content, and changes in GSNOR activity as defense responses in them were studied.

The results indicate that the outcome of tomato cells$B$. cinerea interaction, resistance, or susceptibility, strongly depended on the balance between cell death and survival; the type of cell death seemed to be of special importance. $B$. cinerea infection development was different in the studied cell cultures, especially at the beginning of the interaction. Conidia of the pathogen germinated earlier and formed alive, long, and slender germination tubes in the more susceptible cell cultures whereas in the less susceptible ones, they
Fig. 9 Hydrogen peroxide detected by DAB staining in Perkoz control (a) and B.cinerea inoculated (b) cell cultures and in Corindo control (c) and B. cinerea inoculated (d) cell cultures at 12 hpi. Bar: $20 \mu \mathrm{m}$ is applied to (a-d)

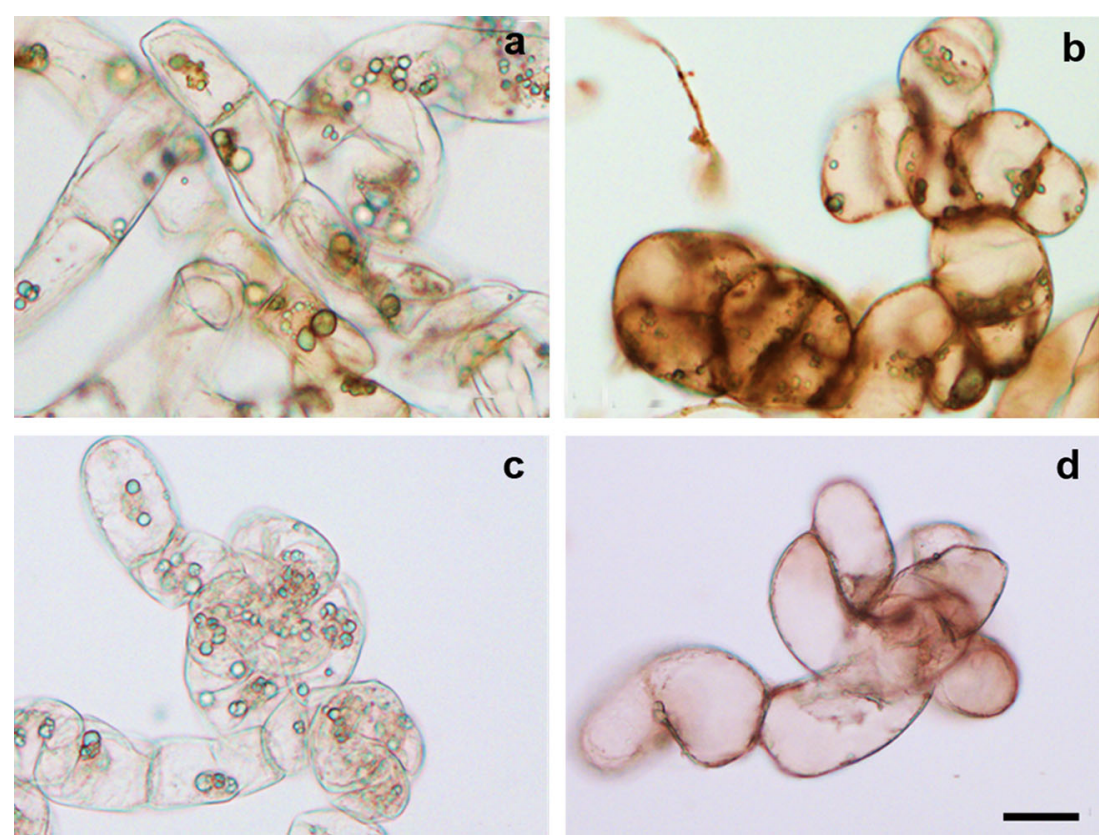




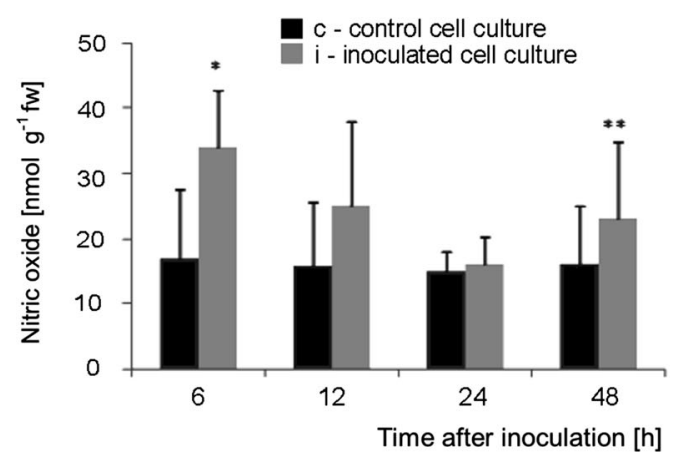

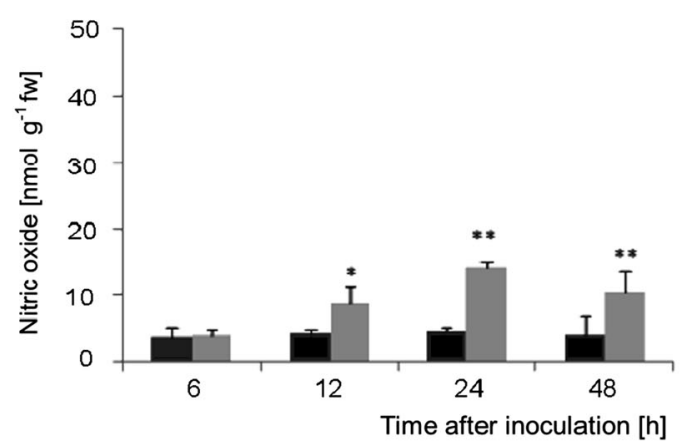

b

Fig 10 Nitric oxide concentration in Perkoz (a) and Corindo (b) cell cultures. Data and statistic as in Fig. $1 ; * P<0.05$ and $* * P<0.01$ indicate values that differ significantly from the control

germinated slowly and formed shorter, swollen germination tubes consisting of cells with yellow-orange nuclei, which suggested that they died in vacuolar type of death (Byczkowska et al. 2013).
Simultaneously the tomato cells died in two different ways in the studied cultures: losses of nuclei or red nuclei indicating necrotic type of death dominated in Corindo cells; in plant cell cultures, this type of death is also described as apoptosis-like
Fig. 11 Nitric oxide detected by DAF-DA staining in Perkoz control (a) and B. cinerea inoculated cell cultures at 6 (b), 12 (c), 24 (d), and 48 (e) hpi as well as in Corindo control (f) and $B$. cinerea inoculated cell cultures at $6(\mathrm{~g})$, 12 (h), 24 (i), and 48 (j) hpi. Bar: $50 \mu \mathrm{m}$ is applied to $(\mathbf{a}-\mathbf{j})$
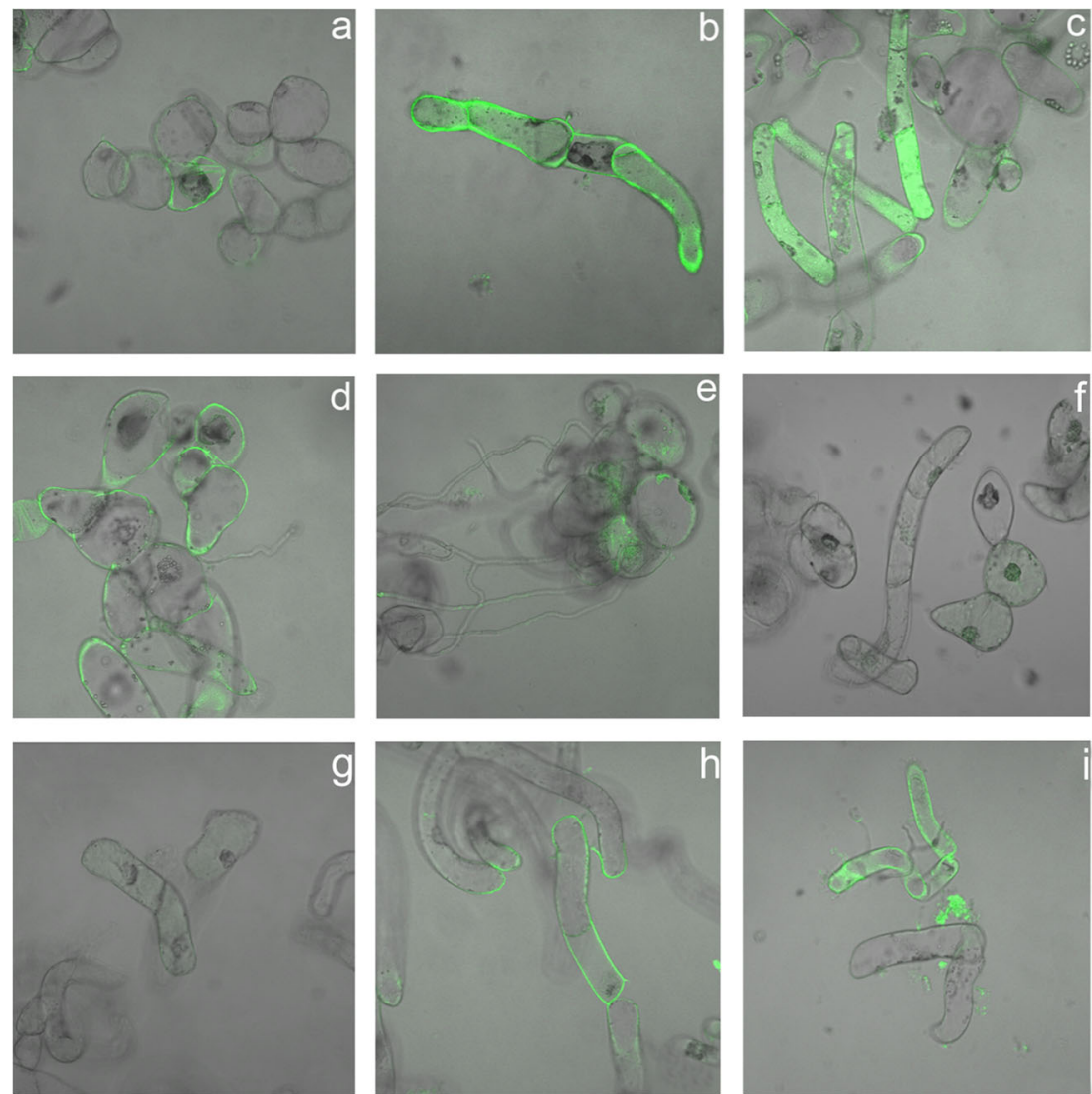

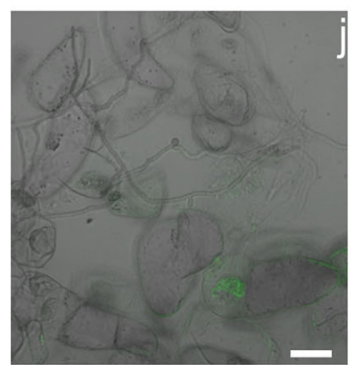




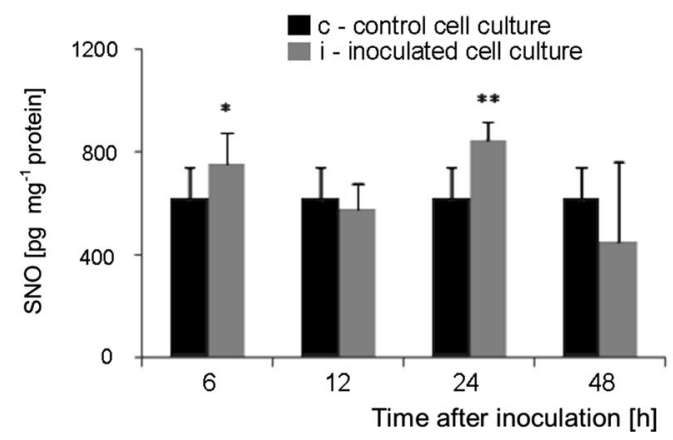

a

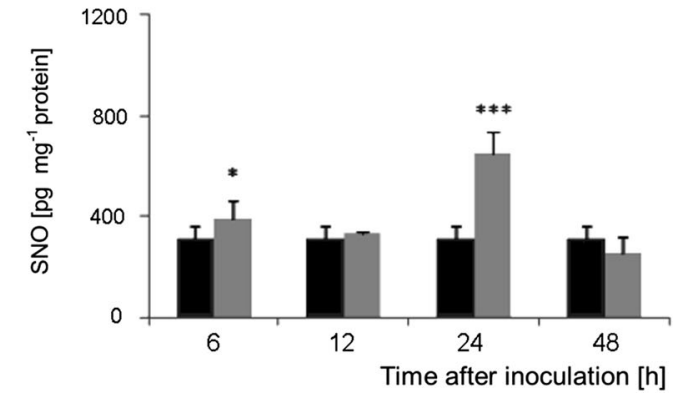

Fig. 12 SNO concentration in Perkoz (a) and Corindo (b) cell cultures. Data and statistic as in Fig. $1 ; * P<0.05,{ }^{* *} P<0.01$, and ${ }^{* * *} P<0.001$ indicate values that differ significantly from the control

(Love et al. 2008). In Perkoz cells, early stages of PCD with different to necrosis symptoms, i.e., green-yellow and yellow nuclei with condensing chromatin were visible, indicating the type of programmed death described in literature (Byczkowska et al. 2013) as vacuolar.

These observations are in agreement with the results of other studies indicating that cell death program leading to rapid necrosis facilitates plant infection by necrotrophic pathogens such as B. cinerea (Dickman et al. 2001; Govrin and Levine 2000; Kars et al. 2005; Perchepied et al. 2010; van Baarlen et al. 2007).

Study on peroxidation of unsaturated lipids in biological membranes, the most prominent symptom of cell damage and marker of oxidative stress, confirmed that after the pathogen inoculation cells in Perkoz culture survived better and their viability was higher than in Corindo culture during the first stages (6-12 hpi) of interaction. The higher increases in lipid peroxidation measured by MDA concentration were demonstrated in Corindo culture, and they persisted throughout the experiment. MDA content increased also in the less susceptible culture but only at the later stages of interaction when both kinds of cell cultures were strongly infected with $B$. cinerea because of very favorable conditions for the pathogen development, e.g., due to presence of sugar and macro- and micronutrients in the culture medium.

Plants develop various strategies to defend themselves against different microbial pathogens. Death of plant cells and necrosis during HR, a well documented type of PCD in plants, characterized by rapid death of cells surrounding infection site, is one of common and effective plant defense strategies especially against biotrophic pathogens feeding on living host tissues (Choi et al. 2013; Iakimova et al. 2013). Cell death during HR may be advantageous for necrotrophs whose success in plant tissue colonization depends on the ability to kill host cells. In different plants, the relationship between cell death in HR and $B$. cinerea invasion is controversial. Research concerning Arabidopsis thaliana, tobacco, and other plants suggest that $B$. cinerea may induce HR cell death to achieve pathogenicity (Dickman et al. 2001; Govrin et al. 2006; van Baarlen et al. 2007; Kars et al. 2005). On the other hand, there are strong suggestions that cell death in HR may be also responsible for plant resistance to necrotrophs, depending on its timing and extent (Kunz et al. 2006; Asselbergh et al. 2007).

NO and ROS are important signaling molecules that are rapidly generated in plants after challenge with pathogens during nitrosative and oxidative burst. These compounds have been strongly implicated in controlling plant resistance and susceptibility. Their cooperation in the process of plant cell death was strongly suggested; the balance between intracellular NO and ROS levels is of special importance (Clarke et al. 2000; Bright et al. 2006; Zaninotto et al. 2006; Yun et al. 2011). Although the roles of ROS and NO and their contribution to plant resistance/susceptibility to pathogens was intensively studied, many details still need elucidation.
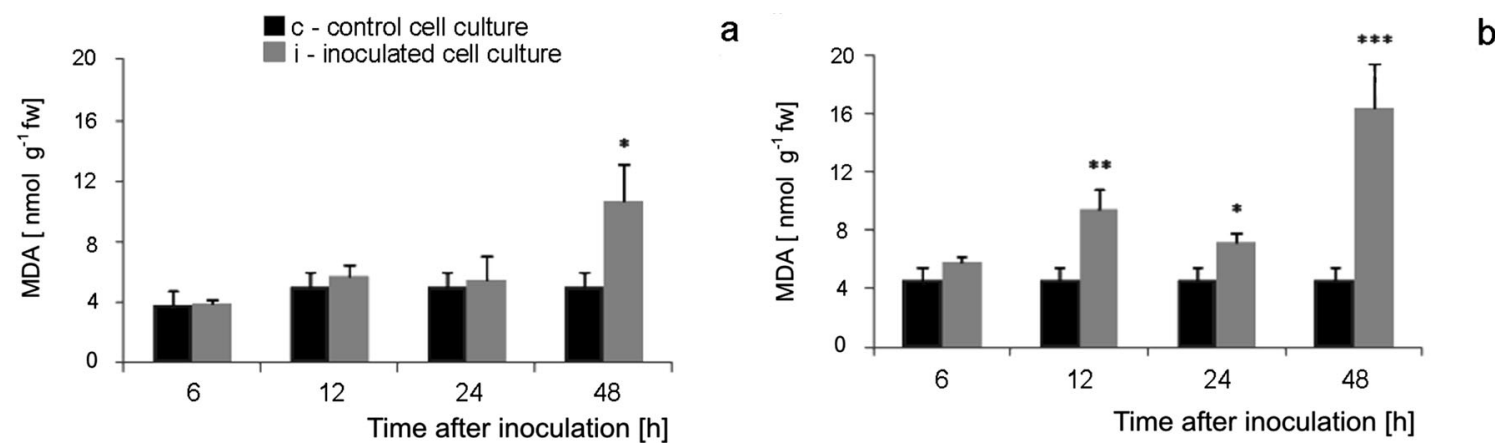

Fig. 13 MDA concentration in Perkoz (a) and Corindo (b) cell cultures. Data and statistic as in Fig. $1 ; * P<0.05, * * P<0.01$, and $* * * P<0.001$ indicate values that differ significantly from the control 

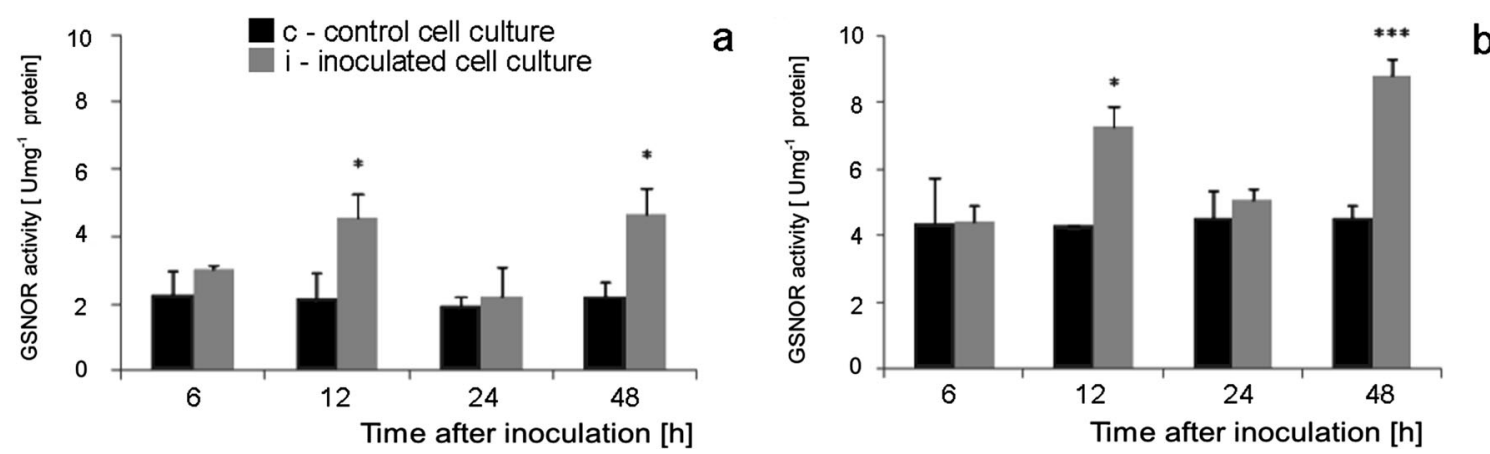

Fig. 14 GSNOR activity in Perkoz (a) and Corindo (b) cell cultures. Data and statistic as in Fig. $1 ; * P<0.05$ and $* * * P<0.001$ indicate values that differ significantly from the control

B. cinerea is a typical necrotroph, and despite extensive research on the biochemical bases of plant resistance mechanisms against this pathogen, the role of ROS and their cooperation with $\mathrm{NO}$ in this process are still controversial and far from clear. It was reported that enhanced ROS generation was found to accompany an infection caused by necrotrophs and even served as their weapon (Tiedemann 1997; Govrin and Levine 2000). On the other hand, some studies suggested positive effect of ROS and NO on plant resistance to necrotrophic pathogens like $B$. cinerea (Asai and Yoshioka 2009; Aziz et al. 2004; Floryszak-Wieczorek et al. 2007; Małolepsza and Urbanek 2002; Rasul et al. 2012).

To explain the role of ROS and NO in tomato- $B$. cinerea interaction two cultivars, more and less susceptible, were used to investigate the $\mathrm{O}_{2}{ }^{-}, \mathrm{H}_{2} \mathrm{O}_{2}, \mathrm{NO}$, and $\mathrm{SNO}$ generation using biochemical and in situ staining methods. As increased production of ROS and NO is a general reaction of plant/cells to different stimuli and may be triggered by different factors such as mechanical stress during biochemical procedures or changing environmental conditions, to eliminate the above, the biochemical study was complemented by in vivo ROS and NO imaging using confocal microscope technique allowing precise localization and determination of the role of $\mathrm{O}_{2}{ }^{-}$, $\mathrm{H}_{2} \mathrm{O}_{2}$, and $\mathrm{NO}$ production/accumulation during tomato cell $-B$. cinerea interaction. The data on NO and ROS distribution acquired by confocal microscopy were generally consistent with the results obtained by the biochemical study. The tomato cell cultures reacted to inoculation with the pathogen with enhanced synthesis of $\mathrm{O}_{2}{ }^{-}$and $\mathrm{H}_{2} \mathrm{O}_{2}$, in parallel burst of NO and some increase in SNO synthesis, were also noted. These phenomena were observed earlier and were more intensive in Perkoz, the less susceptible cell cultures, than in Corindo, the more susceptible ones. It is worth noting that constitutive, pre-inoculation $\mathrm{NO}$ and $\mathrm{SNO}$ concentrations in Perkoz cell cultures were about three and two times higher, respectively, than those in Corindo cultures. The results are in line with those presented by Rasul et al. (2012) that showed that susceptibility of $A$. thaliana plants to $B$. cinerea was related to reduce ability to synthesize NO. A specific role of NO in A. thaliana defense activation against another necrotrophic fungal pathogen, Sclerotinia sclerotiorum was also proved by Perchepied et al. (2010). The correlation between NO production in uninoculated tomato leaves and the level of tomato genotype resistance to biotrophic pathogen Oidium neolycopersici was reported by Piterkova et al. (2009).

Constitutive, pre-inoculation ROS concentration was also higher in Perkoz cell cultures as compared to Corindo ones. Thus both, higher constitutive levels of NO, SNO, and ROS as well as the capacity to produce these compounds faster and more effectively in the less susceptible tomato cells accompanied by slower $B$. cinerea infection development indicate that tomato defense reactions against the pathogen are evident at the cellular level. Moreover, it was observed that the studied cultivars displayed opposite behaviors against fungal infection and that ROS and specially NO and SNO crucially participated in biochemical bases of tomato cells resistance to $B$. cinerea. The molecules may act as direct antimicrobial agents delaying $B$. cinerea conidia germination; moreover, their role as signal molecules for further defense responses is also important (Hong et al. 2008; Perchepied et al. 2010; Romero-Puertas and Delledonne 2003; Wang and Higgins 2005).

Recently, much attention has been paid to the $S$ nitrosylation which is a signal modification.

$S$-nitrosothiols (SNO) also may function as an intracellular reservoir of NO (Chaki et al. 2009). Differences between the concentrations of these compounds in the studied tomato cell cultures before and after inoculation with $B$. cinerea indicated that SNO might also be an important component of signaling pathways triggered in response to $B$. cinerea attack as suggested by Wang et al. (2009) and Hong et al. (2008).

In animal cells, $S$-nitrosoglutathione reductase is a key enzyme responsible for maintaining the homeostasis of $S$ nitrosothiols. Recently, there have been reports suggesting that this enzyme may play a similar role in plant cells (Lin et al. 2012; Malik et al. 2011). Benhar et al. (2009) showed that $S$-nitrosoglutathione reductase protected plant cells and affected defense mechanisms in plant-pathogen interactions, also Gupta et al. (2011) indicated that modulation of GSNOR 
activity in plants had a significant impact on the ability of plants to defend themselves against pathogens.

Two times higher constitutive level of GSNOR activity in Corindo cell cultures as compared to Perkoz ones and increase in the activity of this enzyme in response to the pathogen are conducive to reducing the concentration of SNO in tomato cell cultures and may be related to the susceptibility to $B$. cinerea. Similarly, to our results, transgenic $A$. thaliana plants with reduced amounts of GSNOR and concomitant increased intracellular SNO level have enhanced resistance against Peronospora parasitica (Restérucci et al. 2007). Contrary to that, Feechan et al. (2005) postulated that the reduction of $S$-nitrosothiols concentration as a result of increased GSNOR activity in A. thaliana was related to protection against microbial infection.

In conclusion, we indicated that $B$. cinerea inoculation of two tomato cell cultures differing in susceptibility to the pathogen induced two different types of cell death. The type of cell death accompanied by the characteristics that are proposed to be associated with vacuolar plant cell death dominated in tomato cells less susceptible to the pathogen whereas necrotic/apoptotic-like type of death dominated in more susceptible ones at early stages of interaction.

Constitutive level and speed of NO, SNO, and ROS generation after $B$. cinerea inoculation appear to limit plant cell death and development of necrosis. Moreover, those plant defense molecules might target $B$. cinerea cell death machinery and slow down the pathogen infection development. The results indicate that $\mathrm{NO}, \mathrm{SNO}$, and ROS are important, early signals during the tomato cells $-B$. cinerea interaction and form a part of molecular mechanism of tomato resistance to the pathogen.

Acknowledgments The authors are very grateful to Mrs M. Fronczak for her linguistic correction of the manuscript. This work was supported within the framework of the EU project "Grants to support innovative research postgraduates" under Measure 2.6 of the Integrated Regional Operational Programme.

Open Access This article is distributed under the terms of the Creative Commons Attribution License which permits any use, distribution, and reproduction in any medium, provided the original author(s) and the source are credited.

\section{References}

Asai S, Yoshioka H (2009) Nitric oxide as a partner of reactive oxygen species participates in disease resistance to necrotrophic pathogen Botrytis cinerea in Nicotiana benthamiana. Mol Plant Microbe Interact 22(6):619-629

Asselbergh B, Curvers K, Franca SC, Audenaert K, Vuylsteke M, van Breusegem F, Höfte M (2007) Resistance to Botrytis cinerea in sitiens, an abscisic acid-deficient tomato mutant, involves timely production of hydrogen peroxide and cell wall modification in the epidermis. Plant Physiol 144:1863-1877

Aziz A, Heyraud A, Lambert B (2004) Oligogalacturonide signal transduction, induction of defense-related responses and protection of grapevine against Botrytis cinerea. Planta 218:767-774
Benhar M, Forrester MT, Stamler JS (2009) Protein denitrosylation: enzymatic mechanisms and cellular functions. Nat Rev Mol Cell Biol 10:721-732

Bradford MM (1976) A rapid and sensitive method for the quantitation of microgram quantities of protein utilizing the principle of protein-dye binding. Anal Biochem 72:248-254

Bright J, Desikan R, Hancock JT, Weir IS, Neill SJ (2006) ABA-induced NO generation and stomatal closure in Arabidopsis are dependent on $\mathrm{H}_{2} \mathrm{O}_{2}$ synthesis. Plant J 45:113-122

Byczkowska A, Kunikowska A, Kaźmierczak A (2013) Determination of ACC-induced cell-programmed death in roots of Vicia faba ssp. minor seedlings by acridine orange and ethidium bromide staining. Protoplasma 250:121-128

Capaldi DJ, Taylor KE (1983) A new peroxidase colour reaction: oxidative coupling of 3-methyl-2-benzothiazolinone hydrazone (MBTH) with its formaldehyde azine application to glucose and choline oxidases. Anal Biochem 129:329-36

Chaki M, Fernández-Ocańa AM, Valderrama R, Carreras A, Esteban FJ, Luque F, Gómez-Rodríguez MV, Begara-Morales JC, Corpas FJ, Barroso JB (2009) Involvement of reactive nitrogen and oxygen species (RNS and ROS) in sunflower-mildew interaction. Plant Cell Physiol 50(2):265-279

Chandler MT, de Marsac TN, De Kouchkovsky Y (1972) Photosynthetic growth of tobacco cells in liquid suspension. Can J Bot 50:22652270

Choi HW, Kim NH, Lee YK, Hwang BK (2013) The pepper extracellular xyloglucan - specific endo- $\beta$-1,4-glucanase inhibitor protein gene, CaXEGIP1, is required for plant cell death and defense responses. Plant Physiol 161:384-396

Clarke A, Desikan R, Hurst RD, Hancock JT, Neill SJ (2000) NO way back: nitric oxide and programmed cell death in Arabidopsis thaliana suspension cultures. Plant J 24:667-677

De Pinto MC, Locato V, de Gara L (2012) Redox regulation in plant programmed cell death. Plant Cell Environ 325:234-244

Delledonne M, Zeier J, Marocco A, Lamb C (2001) Signal interaction between nitric oxide and reactive oxygen intermediates in the plant hypersensitive disease resistance response. Proc Natl Acad Sci U S A 98:13454-13459

Dickman MB, Parkl YK, Oltersdorf T, Li W, Clemente T, French R (2001) Abrogation of disease development in plants expressing animal antiapoptotic genes. Proc Natl Acad Sci U S A 98:13454 13459

Ding AH, Nathan CF, Stuehr DJ (1988) Release of reactive nitrogen intermediates and reactive oxygen intermediates from mouse peritoneal macrophages. Comparison of activating cytokines and evidence for independent production. J Immunol 141(7):2407-2412

Doke N (1983) Involvement of superoxide generation in the hypersensitive response of potato tuber tissues to infection with an incompatible race of Phytophthora infestans and to hyphal wall components. Physiol Plant Pathol 23:345-357

Elad Y, Williamson B, Tudzynski P, Delen N (2007) Botrytis: biology, pathology and control. Springer, Dordrecht

Feechan A, Kwon E, Yun BW, Wang Y, Pallas JA, Loake GJ (2005) A central role for $S$-nitrosothiols in plant disease resistance. Proc Natl Acad Sci U S A 102(22):8054-8059

Finkers R, van den Berg P, van Berloo R, ten Have A, van Heusden AW, van Kann JAL, Lindhout P (2007) Three QTLs for Botrytis cinerea resistance in tomato. Theor Appl Genet 114:585-593

Floryszak-Wieczorek J, Arasimowicz M, Milczarek G, Jeleń H, Jackowiak H (2007) Only an early nitric oxide burst and the following wave of secondary nitric oxide generation enhanced effective defence responses of pelargonium to a necrotrophic pathogen. New Phytol 175:718-730

Foissner I, Wendehenne D, Langebartels C, Durner J (2000) In vivo imaging of an elicitor-induced nitric oxide burst in tobacco. Plant $\mathrm{J}$ 23:817-824 
Govrin EM, Levine A (2000) The hypersensitive response facilitates plant infection by the necrotrophic pathogen Botrytis cinerea. Curr Biol 10:751-757

Govrin EM, Rachmilevitch S, Tiwari BS, Salomon M, Levine A (2006) An elicitor from Botrytis cinerea induces the hypersensitive response in Arabidopsis thaliana and other plants and promotes the grey mold disease. Phytopathol 96(3):299-307

Gupta KJ, Fernie AR, Kaiser WM, van Dongen JT (2011) On the origins of nitric oxide. Trends Plant Sci 16(3):160-168

Hong JK, Yun BW, Kang JG, Raja MU, Kwon E, Sorhagen K, Chu C, Wang Y, Loake GJ (2008) Nitric oxide function and signaling in plant disease resistance. J Exp Bot 59(2):147-154

Iakimova ET, Sobiczewski P, Michalczuk L, Wegrzynowicz-Lesiak E, Mikicinski A, Woltering EJ (2013) Morphological and biochemical characterization of Erwinia amylovora -induced hypersensitive cell death in apple leaves. Plant Physiol Biochem 63:292-305

Kanai R, Edwards GE (1973) Purification of enzymatically isolated protoplasts from $\mathrm{C}_{3}, \mathrm{C}_{4}$ and crassulacean acid metabolism plants using aqueous dextran-polyethylene glycol two-phase system. Plant Physiol 52:484-490

Kars I, Krooshof GH, Wagemakers L, Joosten R, Benen JA, van Kan JAL (2005) Necrotizing activity of five Botrytis cinerea endopolygalacturonases produced in Pichia pastoris. Plant J 43: 213-225

Kobori S, Masuda Y, Horii M, Marubashi W (2007) High levels of the cytokinin BAP suppress programmed cell death in hybrid tobacco cells (Nicotiana suaveolens $\mathrm{x}$ N. tabacum) expressing hybrid lethality. Plant Biotech 24:375-381

Kunz C, Vandelle E, Rolland S, Poinsot B, Bruel C, Cimerman A, Zotti C, Moreau E, Vedel R, Pugin A, Boccara M (2006) Characterization of a new, nonpathogenic mutant of Botrytis cinerea with impaired plant colonization capacity. New Phytol 170:537-550

Lin A, Wang Y, Tang J, Xue P, Li C, Liu L, Hu B, Yang F, Loake GJ, Chu C (2012) Nitric oxide and protein $S$-nitrosylation are integral to hydrogen peroxide-induced leaf cell death in rice. Plant Physiol 158:451-464

Lindermayr C, Saalbach G, Durner J (2005) Proteomic identification of $S$ nitrosylated proteins in Arabidopsis. Plant Physiol 137:921-930

Liu L (2001) A metabolic enzyme for $S$-nitrosothiol conserved from bacteria to humans. Nature 410:490-494

Love AJ, Milner JJ, Sadanandom A (2008) Timing is everything: regulatory overlap in plant cell death. Trends Plant Sci 13(11):589-595

Malik SI, Hussain A, Yun BW, Spoel SH, Loake GJ (2011) GSNORmediated de-nitrosylation in the plant defence response. Plant Sci $181: 540-544$

Małolepsza U, Urbanek H (2002) o-Hydroxyethylorutin-mediated enhancement of tomato resistance to Botrytis cinerea depends on a burst of reactive oxygen species. J Phytopathol 150:616-624r

Oirdi ME, Rahman TAE, Rigano L, Hadrami AE, Rodriguez MC, Daayf F, Vojnov A, Bouarab K (2011) Botrytis cinerea manipulates the antagonistic effects between immune pathways to promote disease development in tomato. Plant Cell 23:2405-2421

Orozco-Cárdenas M, Ryan CA (1999) Hydrogen peroxide is generated systemically in plant leaves by wounding and systemin via the octadecanoid pathway. Proc Natl Acad Sci U S A 96(11):6553-6557

Peng M, Kuć J (1992) Peroxidase-generated hydrogen peroxide as a source of antifungal activity in vitro and on tobacco leaf disks. Phytopathol 82:696-699

Perchepied L, Balague C, Riou C, Claudel-Renard C, Riviere N, GrezesBesset B, Roby D (2010) Nitric oxide participates in the complex interplay of defense-reated signaling pathways controlling disease resistance to Sclerotinia sclerotiorum in Arabidopsis thaliana. Mol Plant Microbe Interact 23(7):846-860
Piterkova J, Petrivalsky M, Luhova L, Mieslerova B, Sedlarova M, Lebeda A (2009) Local and systemic production of nitric oxide in tomato responses to powdery mildew infection. Mol Plant Pathol 10(4):501-513

Rasul S, Dubreuil-Maurizi C, Lamotte O, Koen E, Poinssot B, Alcaraz G, Wendehenne D, Jeandroz S (2012) Nitric oxide production mediates oligogalacturonide - triggered immunity and resistance to Botrytis cinerea in Arabidopsis thaliana. Plant Cell Environ 35:1483-1499

Restérucci C, Espunya CE, Diaz M, Chabannes M, Martinez MC (2007) $S$-nitrosoglutathione reductase affords protection against pathogens in Arabidopsis, both locally and systemically. Plant Physiol 143(3): 1282-1292

Ribble D, Goldstein NB, Norris DA, Shellman YG (2005) A simple technique for quantifying apoptosis in 96-well plates. BMC Biotechnol 15:1-7

Romero-Puertas M, Delledonne M (2003) Nitric oxide in plant-pathogen interactions. IUMB Life 55:579-583

Sakamoto A, Ueda M, Morikawa H (2002) Arabidopsis glutathionedependent formaldehyde dehydrogenase is an $S$-nitrosoglutathione reductase. FEBS Lett 515(1-3):20-24

Shlezinger N, Minz A, Gur Y, Hatam I, Dagdas YF, Talbot NJ, Sharon A (2011) Anti-apoptotic machinery protects the necrotrophic fungus Botrytis cinerea from host-induced apoptotic-like cell death during plant infection. PLoS Pathog 7(8):1-12

Tiedemann AV (1997) Evidence for a primary role of active oxygen species in induction of host cell death during infection of bean leaves with Botrytis cinerea. Physiol Mol Plant Pathol 50:151-166

Trujillo M, Kogel KH, Hückelhoven R (2004) Superoxide and hydrogen peroxide play different roles in the nonhost interaction of barley and wheat with inappropriate formae speciales of Blumeria graminis. Mol Plant Microbe Interact 17(3):304-312

Unger C, Kleta S, Jandl G, von Tiedemann AV (2005) Supression of the defence-related oxidative burst in bean leaf tissue and bean suspension cells by the necrotrophic pathogen Botrytis cinerea. J Phytopathol 153:15-26

Van Baarlen P, Woltering EJ, Staats M, van Kan JAL (2007) Histochemical and genetic analysis of host and non-host interactions of Arabidopsis with three Botrytis species: an important role for cell death control. Mol Plant Pathol 8:41-54

Van Doorn WG, Beers EP, Dangl JL, Franklin-Tong VE, Gallois P, HaraNishimura I, Jones AM, Kawai-Yamada M, Lam E, Mundy J, Mur LAJ, Smertenko A, Taliansky M, van Breusegem F, Wolpert T, Woltering E, Zhivotovsky B, Bozhkov PV (2011) Morphological classification of plant cell deaths. Cell Death Differ 18(8):1241-6

Wang J, Higgins VJ (2005) Nitric oxide has a regulatory effect in the germination of conidia of Colletotrichum coccodes. Fungal Genet Biol 42:284-292

Wang YQ, Feechan A, Yun BW, Shafiei R, Hofmann A, Taylor P, Xue P, Yang FQ, Xie ZS, Pallas JA, Chu CC, Loake GJ (2009) $S$ Nitrosylation of AtSABP3 antagonizes the expression of plant immunity. J Biol Chem 284(4):2131-2137

Williamson B, Tudzynski B, Tudzynski P, van Kan JAL (2007) Botrytis cinerea: the cause of grey mould disease. Mol Plant Pathol 8(5): $561-580$

Yagi K (1976) A simple fluorometric assay for lipoperoxide in blood plasma. Biochem Med 15:212-216

Yun BW, Feechan A, Yin M, Saidi NBB, Bihan LT, Yu M, Moore JW, Kang JG, Kwon E, Spoel SH, Pallas JA, Loake GJ (2011) Snitrosylation of NADPH oxidase regulates cell death in plant immunity. Nature 478:264-268

Zaninotto F, La Camera S, Polverari A, Delledonne M (2006) Cross talk between reactive nitrogen and oxygen species during the hypersensitive disease resistance response. Plant Physiol 141:379-383 